\title{
Quality and Affordable Education through Quality Management Systems in Higher Education
}

\author{
Muhammad Afif Hasbullah \\ Universitas Islam Darul Ulum, Lamongan, Indonesia \\ afif@unisda.ac.id \\ Nisaul Barokati Selirowangi \\ Universitas Islam Darul Ulum, Lamongan, Indonesia \\ nisa@unisda.ac.id \\ Mohammad Syaiful Pradana \\ Universitas Islam Darul Ulum, Lamongan, Indonesia \\ syaifulp@unisda.ac.id \\ Buyun Khulel \\ Universitas Islam Darul Ulum, Lamongan, Indonesia \\ buyunkhulel@unisda.ac.id \\ Moh Hudi \\ Universitas Islam Darul Ulum, Lamongan, Indonesia \\ moh.hudie@gmail.com
}

\begin{tabular}{ll}
\hline Article History: & Received: Oct $12^{\text {th }} 2019$ \\
& Revised: Feb $13^{\text {th, } 2020}$ \\
& Accepted: March $30^{\text {th, } 2020}$
\end{tabular}

\begin{abstract}
The general goal of education is to develop Indonesian people completely in the sense that carried out education still maintain unity, diversity and develop individual's ideals. Every citizen has the right to obtain education equally with excellence and a balance (equity) between the utilization (access) with achievement. The higher education system must be able to create a quality higher education that is also affordable by the people of Indonesia. A university leader must be in-line and lead a "quality revolution". All energy and attention are focused on the "quality revolution". For this reason, this paper will examine the Implementation of Higher Education Quality Management Systems. As a case study is that has implemented a Quality Management System. According to Law No. 12 of 2012 concerning Higher Education. Quality Higher Education is Higher Education that produces graduates who are able to actively develop their potential and produce Science and / or Technology that is useful for the Community, nation, and country. The government operates a higher education quality assurance system to get quality education. The Higher Education quality assurance system referred to consists of: a. internal quality assurance system developed by Higher Education; and b. external quality assurance system carried out through accreditation. Implementation of Quality Management Systems in Higher Education can produce Quality and Affordable Education.
\end{abstract}

Keywords: Education, Quality, Affordable, Higher Education, QMS 


\section{INTRODUCTION}

Education in Indonesia is strived to develop gradually. Developments are expected to occur at all levels of education, including at the tertiary level. Many attempts have been made by those who have an interest in education in Indonesia, both by the government and by the private sector. The efforts made cover many aspects such as curriculum structure development, human resource development and organizational development by educational institutions.

The government attempts to develop education in Indonesia through policies related to education. These policies are subsequently implemented by existing educational institutions. Meanwhile, the private sector contributes to the development of education through investments in the development of educational institutions and the provision of education both formal and nonformal education. Implementation of the development of institutions by educational institutions is determined by the ability of educational institutions in organizing their education. As an organization, educational institutions also include managerial elements in its management, especially educational institutions that are built by the private sector.

The managerial system is used by educational institutions to manage all components in the educational institution. The implementation of a managerial system requires every organization to have a strategic plan. Strategic plan is a process to examine the current situation of an organization or community and project it into the future, formulate goals, develop strategies to achieve these goals, and measure the results, and further improvement a number of fundamental stages (Osborne and Gaebler, 2000 ). The strategic plan is useful as a reference for implementing an organizational development program in order to achieve the goals of an organization. Making strategic plan can eliminate the possibility of major mistakes in the execution and eliminate unpredictability conditions that may arise in operations. Strategic plan is very good for businesses that require a long time between decisions and their impact in the implementation process.

Quality measures can be seen from both two types of products produced, namely whether in the form of goods and services. For products in the form of goods, quality can be measured by the following things:

1. Design, based on market research, is influenced by factors of input quality, the technology used, and the quality of the employees and the managers.

2. Performance, namely the reliability of product is measured by time of use before the product is damaged, and maintenance of product is by repairing, or replacing damaged products.

3. Conformance, according to the noted specifications including technical life of product, impact of product, and accuracy of product.

For products in the form of services, quality can be measured by the following terms:

1. Tangibles: the appearance of tools physical facilities, human resources, and communication tools.

2. Reliability: the ability to provide services as promised.

3. Responsiveness: the ability and the capability to help consumers and to provide services according to regulations.

4. Assurance: ethics, knowledge, attitudes in dealing with consumers.

5. Empathy: accuracy of work, caring, ability to pay attention to consumers.

The factors that influence product quality are as follows:

1. Market, customers or consumers as product users.

2. The purpose of the organization, for high / low output volumes, product prices, or exclusive expensive products.

3. Product testing.

4. Product design. 
5. Production process.

6. Input quality.

7. Equipment maintenance.

8. Quality standards in organizations.

9. Customer feedback.

Quality control is needed to reduce errors, to maintain, to raise quality according to standards, to reduce consumer complaints, to enable output grading, to obey regulations, and to maintain and to enhance company image.

According to Law no. 12 of 2012 concerning Higher Education states that higher education as part of the national education system has a strategic role in educating the life of the nation and advancing science and technology by paying attention to and applying the value of the humanities as well as the culture and empowerment of the Indonesian nation in a sustainable manner. To increase the nation's competitiveness in facing globalization in all fields, higher education that is able to develop science and technology and produce intellectuals, scientists, and / or professionals who are cultured and creative, tolerant, democratic, resilient in character, and dare to defend the truth for the benefit of the nation is needed.

To create affordability and equitable distribution in obtaining quality higher education that is relevant to the interests of the community for progress, independence, and welfare, the arrangement of higher education in a planned, targeted and sustainable tertiary education by paying attention to demographic and geographical aspects is needed.

The function of higher education is that Higher Education functions:

1. Developing capabilities and forming a dignified character and civilization of the nation in the context of developing the intellectual life of the nation;

2. Developing an innovative, responsive, creative, skilled, competitive, and cooperative academic community through the implementation of Tridharma; and

3. Developing Science and Technology by paying attention and applying the value of Humanities

The Director General of Higher Education has established a Higher Education Long Term Strategy (abbreviated as HELTS) which states: In order to contribute to the nation's competitiveness, the national higher education bas to be organizationally bealthy, and the same requirements also apply to institutions. A structural adjustment in the existing system is, however, needed to meet this challenge. The structural adjustment aims, by the year of 2010, of having a healthy higher education system 1, effectively coordinated and demonstrated by the following features: Quality; Access, equity; and Autonomy.

Thus, at this time it is necessary to make structural adjustments to the national higher education system, to produce a healthy higher education system, which is effectively coordinated and demonstrated by the characteristics of quality, access and justice, and autonomy. Furthermore, particularly about the quality characteristics of national higher education, stated specifically about Quality Assurance as follows: In a healthy organization, a continuous quality improvement should become its primary concern. Quality assurance should be internally driven, institutionalized within each organization's standard procedures, and could also involve external parties. However, since quality is also a concern of all stakeholders, quality improvement should aim at producing quality outputs and outcomes as part of public accountability.

Higher Education needs to design and to arrange Higher Education Quality Assurance Guidelines, which will be used as guidelines by tertiary institutions to carry out quality assurance processes, on their own initiative (internally driven). In addition to carrying out the process of guaranteeing the quality of higher education on its own initiative, at present, the university can also carry out the accreditation process through the National Accreditation Board of Higher Education (BAN-PT) 
or other institutions both at domestic and abroad, as well as evaluating the Study Program Based on Self Evaluation (EPSBED). So that the three types of activities aimed at achieving the quality of higher education on an ongoing basis (continuous quality improvement) can mutually support and complement each other, it is necessary to make goals, status, and institutions that handle each of these activities, as follows:

Table 1. Evaluation Items for College

\begin{tabular}{|l|l|l|l|}
\hline Activity & Purpose & Status & Institution \\
\hline Accreditation & $\begin{array}{l}\text { external quality control and audit } \\
\text { of education }\end{array}$ & Facultative & $\begin{array}{l}\text { BAN-PT or other } \\
\text { institutions }\end{array}$ \\
\hline EPSBED & extension of operational licenses & Required & Ditjen Dikti \\
\hline $\begin{array}{l}\text { Quality } \\
\text { Assurance }\end{array}$ & $\begin{array}{l}\text { improve the quality of education } \\
\text { internally }\end{array}$ & college initiative & $\begin{array}{l}\text { The college } \\
\text { concerned }\end{array}$ \\
\hline
\end{tabular}

The following section of this paper explains about Quality Assurance, Quality Management System and Implementation of Quality Control Management which is recommended by the Implementation of Quality Management System at Unisda Lamongan through the Implementation of ISO 9001: 2008 Quality Management System.

\section{QUALITY ASSURANCE}

The process of quality assurance of higher education in particular college is an independent activity of that relevant college, so that the process is designed, carried out, and controlled by the relevant college. Each college has different specifications, including in terms of size, structure, resources, vision and mission, history, and leadership. According to Goedegebuure: It has been suggested that the more governments move in the direction of self-regulation and steering at a distance, the more they will seek to promote the strengthening of managerial authority within institutions as well as improved systems of accountability.

Regarding the position and importance of quality assurance of higher education in particular college, it can be stated that in the future the existence of a particular college does not depend solely on the government, but mainly depends on the assessment of stakeholders (students, parents, the world of work, the government, lecturers, supporting staff, as well as other interested parties) about the quality of higher education that is organized. In order for its existence to be guaranteed, the college must inevitably carry out a quality assurance of higher education that is organized. It should be noted that because stakeholder assessments are constantly evolving, quality assurance must also be adjusted to that development continuously (continuous improvement). The factors that are generally contained in the process of higher education quality assurance include formulation or definition, concepts, objectives, strategies, quality items, processes, and quality control management in the process of higher education quality assurance.

\section{Definition of Quality Assurance}

In general what is meant by quality assurance is the process of establishing and determining management quality standards in a consistent and sustainable manner, so that consumers, producers, and other interested parties obtain the satisfaction. Thus, higher education quality assurance is the process of establishing and determining the quality standards of higher education management consistently and continuously, so that stakeholders get the satisfaction.

\section{The Concept of Quality Assurance}

Higher education in higher education is declared to be of quality or quality, if: 
a. The university is able to set and realize its vision through the implementation of its mission (deductive aspects);

b. The university is able to meet the needs of stakeholders (inductive aspects), in the form of:

- social needs (societal needs);

- the needs of the world of work (industrial needs);

- professional needs (professional needs.

Thus the tertiary institution must be able to plan, carry out, and control a process that guarantees the achievement of quality as described above.

\section{The purpose of Quality Assurance}

Maintain and improve the quality of higher education on an ongoing basis, which is carried out by a tertiary institution internally to realize its vision and mission, as well as to meet the needs of stakeholders through the organization of Higher Education Tridharma. Achievement of the objectives of quality assurance through quality assurance activities carried out internally by tertiary institutions, will be controlled and audited through accreditation activities carried out by BAN-PT or other institutions externally. Thus, the objectivity of the assessment of the maintenance and improvement of the quality of higher education on an ongoing basis in a tertiary institution can be realized, as can be seen in Figure 1.

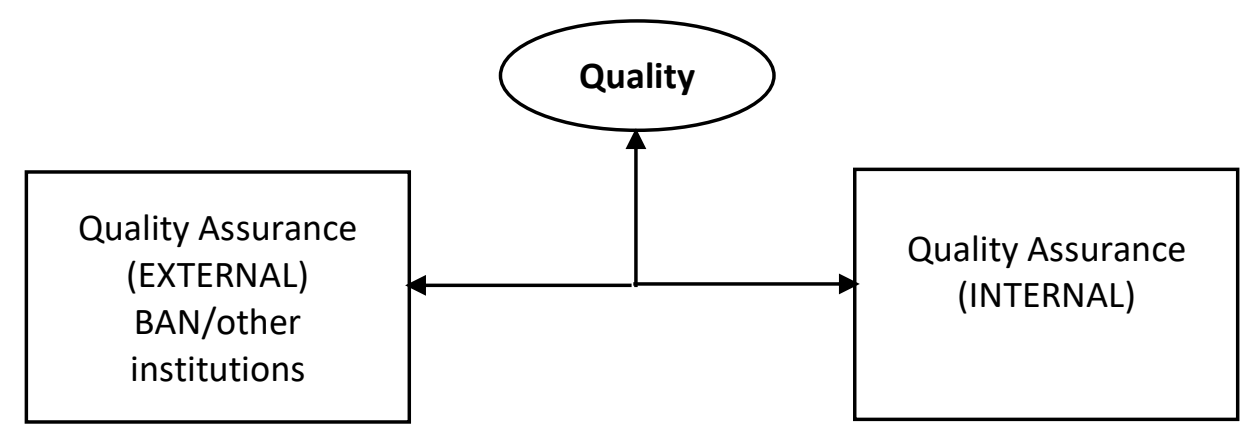

Figure 1. College's Quality Maintenance and Improvement

\section{Quality Assurance Strategies}

Strategies for quality assurance in higher education in Indonesia are:

a. The Directorate General of Higher Education, Ministry of National Education sets

Guidelines for the Quality Assurance of Higher Education in Higher Education;

b. The college establishes a commitment to carry out quality assurance of higher education that it organizes;

c. The college chooses and sets its own higher education quality standards for each study program;

d. The college stipulates and runs an organization along with a mechanism of work of higher education quality assurance;

e. The college will benchmark the quality of higher education on an ongoing basis, both inside and outside the country.

\section{Quality Items}

As stated above, the college chooses and sets their own higher education quality standards for each study program. The selection and determination of standards is carried out in a number of aspects called quality items, including: 
- Study program curriculum;

- Human resources (lecturers, and supporting staff);

- College students;

- Learning process;

- Infrastructure and facilities;

- Academic atmosphere;

- Finance;

- Research and publications;

- Community service;

- Governance;

- Institutional management;

- Information Systems;

- Domestic and international cooperation.

\section{Quality Assurance Process}

Quality assurance of higher education in the college is carried out through the stages arranged in a process as follows:

a. The college establishes the vision and mission of the relevant college;

b. Based on the vision and mission of the college, each study program determines the vision and mission of the study program;

c. The vision of each study program is then translated by the related study program into a series of quality standards on each quality item as mentioned above;

d. Quality standards are formulated and established by formulating the vision of the college (deductively) and the needs of stakeholders (inductively). As a standard, the formula must be specific and measurable that contains elements of ABCD (Audience, Behavior, Competence, Degree);

e. The college establishes the working organization and mechanism of quality assurance;

f. The college carries out quality assurance by implementing the quality control management below;

g. The college evaluates and revises quality standards through continuous benchmarking.

\section{Quality Management System}

Quality management of higher education in the college can be carried out through various quality control management models. One of management models that can be used is the PDCA (Plan, Do, Check, Action) model which will result in continuous improvement or kaizen quality of higher education in the college. The PDCA management model can be seen in Figure 2.

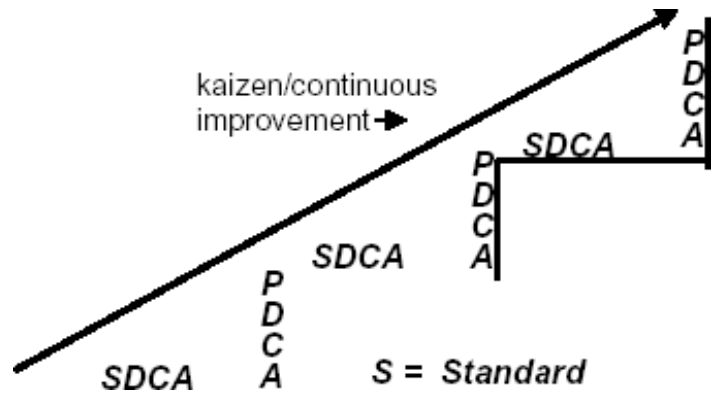

Figure 2. $P D C A$ management model 
Some principles that must underlie the mindset and action patterns of all PDCA-based quality control management practitioners are:

a. Quality first

All thoughts and actions of the college manager must prioritize quality;

b. Stakeholder-in

All thoughts and actions of the collage manager must be aimed at stakeholder satisfaction;

c. The next process is our stakeholders

Everyone who implements a task in the higher education process, must consider others who use the results of the implementation of their duties as stakeholders who must be satisfied;

d. Speak with data

Everyone implementing higher education must take action and make decisions based on the analysis of data that has been obtained in advance, not based on presupposition or manipulation;

e. Upstream management

All decision making in the higher education process is participatory, not authoritative. In the 'check' stage of the PDCA-based quality control management, there are quality check points where each person implementing higher education must audit the results of implementing their duties with established quality standards. For example the formative test action carried out at the end of each subject, is a quality control point in the learning process, which is carried out to audit whether the quality standards of learning as formulated in the form of Special Instructional Objectives (ICT) have been achieved. If the audit results are positive in the sense that they have reached the quality standard (S in SDCA) as formulated in ICT, then in the planning process or Plan (P in PDCA) the next quality standard must be raised, so that there will be a kaizen of higher education quality, as described in in Figure 3 above. Whereas, if the evaluation results are negative in the sense that the quality standards as formulated in ICT have not been or have not been achieved yet, actions must be taken immediately (Action in PDCA) so that the quality standards can be achieved. For example, if the Formative Test shows that the results are under ICT, the lecturer must perform an Action (A in the PDCA) which can be in the form of repetition of the relevant subject matter until ICT can be achieved. Therefore, setting quality control points (quality check-points) for each activity unit in PDCAbased quality control management, is a conditio sine qua non or a must. Quality control management in higher education quality assurance can be seen in Figure 3. 


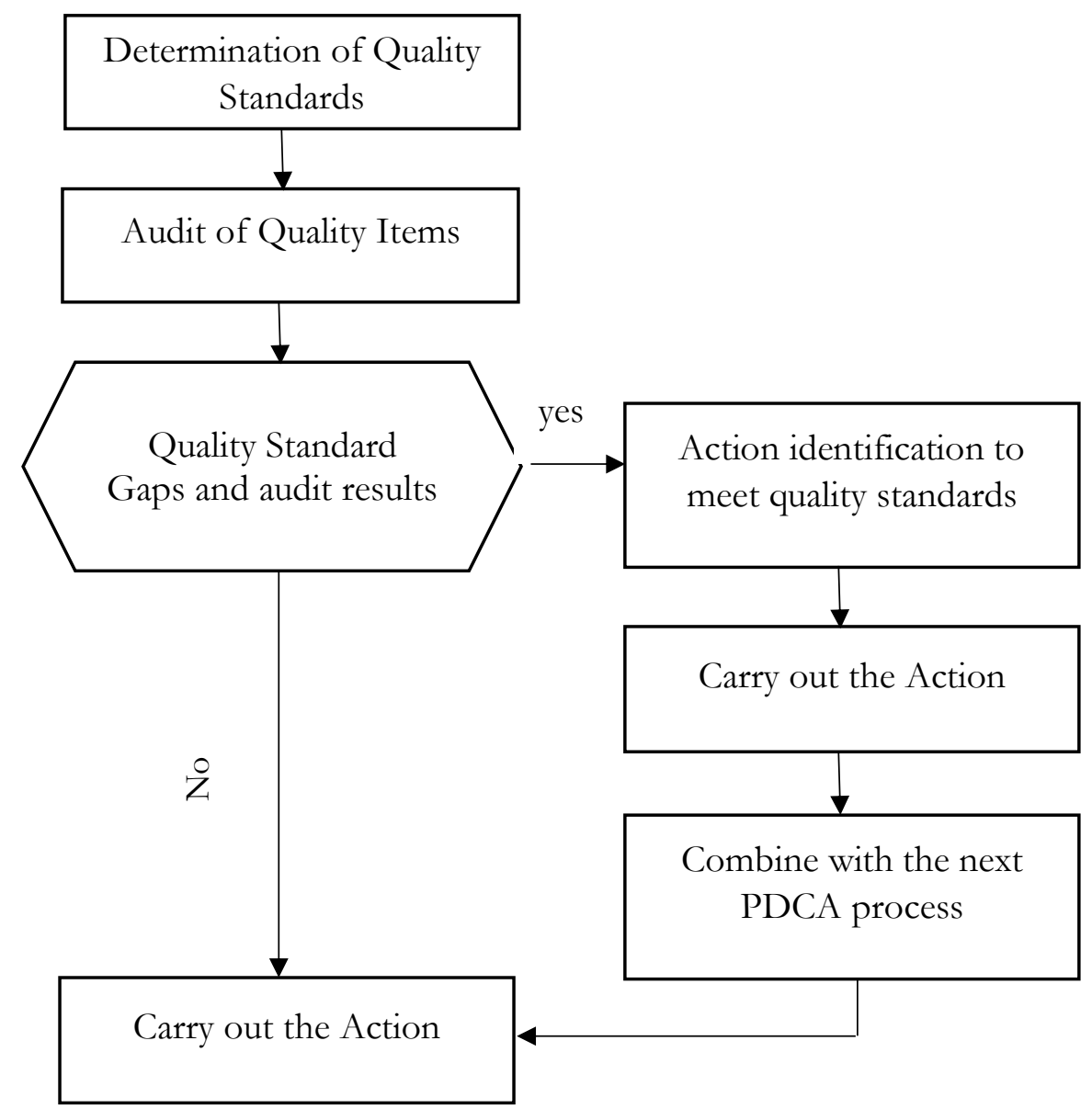

Figure 3. Quality control management

\section{IMPLEMENTATION OF QUALITY ASSURANCE}

That the quality assurance of higher education in the college can be carried out, there are several prerequisites that must be fulfilled so that the implementation of quality assurance can achieve its objectives, namely commitment, paradigm change, and the mental attitude of the practitioners of the higher education process, as well as organizing quality assurance in higher education.

\section{Commitment}

The practitioners of the higher education process in the college, both those who lead and those who are led, must have a high commitment to always guarantee and improve the quality of the higher education that they organize. Without this commitment in all lines of organization of the college, undoubtedly the guarantee of the quality of higher education in the college will run stagnant, it may not even be successful. There are various ways that can be chosen to weld commitment from all lines in the college, depending on the size, structure, resources, vision and mission, history, and leadership of / in the college.

2. Change of Paradigm

The old paradigm of quality assurance, the quality of higher education in the college will be able to be maintained and improved if there is strict supervision or control by the government (dhi. Ditjen Dikti Depdiknas), it must be changed into a new paradigm.

The new paradigm of higher education quality assurance, the college must maintain and improve the quality of higher education that is held so that the vision can be realized through the 
implementation of the mission, and so that the stakeholders can be satisfied. With this new paradigm, the task of supervision by the government is lightened, the accountability of the college increases, stakeholders play a greater role in determining the quality of higher education in the college.

3. Mental Attitude

It must be acknowledged that the majority of the college in Indonesia carry out higher education without prior planning. It can be stated the fact that on the macro scale, the Master Plan for Development (RIP) of the college, is mostly prepared to meet the accreditation requirements, while on the micro scale the facts that low percentage of lecturers making learning plans in the form of Lecture Program Unit (SAP), and there are many more facts that show that a college runs higher education without planning. Even if there is planning, it is generally not because of necessity, but because of licensing or accreditation requirements. Such mental attitude must be changed to a new mental attitude, that is, plan your work and work on your plan (plan your work. and work your plan).

\section{Organizing}

Regarding the organization and work mechanism of higher education quality assurance organizations in the college, there is no standard pattern that must be followed by all of the college. The organization of higher education quality assurance in the college depends a lot on the size, structure, resources, vision and mission, history, and leadership of / at the college. For example, it can be argued that a college can establish a quality assurance unit within its organizational structure led by a vice-rector, or an independent unit apart of the organizational structure led by a lecturer. Another example of an organizing model is the inherent or built-in quality assurance activities in the management process of higher education in the relevant college. As such there is no need for a special organizational unit led by officials who handle quality assurance in higher education. The freedom to determine the model of organizing higher education quality assurance at each college, is in accordance with the independent character of the college in Indonesia in the future. The most important factor that needs attention in organizing higher education quality assurance, is that the organization is able to boost an understanding of higher education quality assurance in the college, which in turn will boost supportive attitudes of all components of the college towards higher education quality assurance efforts .

\section{CONCLUSION}

From the above article conclusions can be drawn as follows:

1. Quality Management System is a management system for directing and controlling an organization based on quality which aims to enable the organization to demonstrate its ability to provide products or services consistently and increase customers' satisfaction.

2. In the case of ST'T Multimedia Cendekia Abditama, what is meant by the customer is a student, so that all available resources are made as much as possible in order to achieve students' satisfaction starting from the students' registeration until graduation.

3. That to be able to compete and produce good graduates, universities can prepare a Quality Management System oriented to customers' satisfaction. Because customers' assessment is constantly evolving, the Quality Management System that is developed must always be adjusted to that development continuously (continuous improvement).

4. Quality Management System can improve the Quality of the Collage.

5. With a Quality Management System, the College can carry out existing processes more effectively and efficiently so as to reduce existing costs, so that in turn can produce an affordable education system. 


\section{REFERENCES}

Assumption University -Thailand, Quality Assurance Manual, AuQS 2008 Center for Exellence, 2001;

Brennan, J. and Shah, T., Managing Quality in Higher Education, OECD, SRHE and Open University Press, Buckingham, 2000;

Dale H. Besterfielld et all (2003), Total Quality Manajemen, Pearson Education International

David J. Skyrme (2001), Capitalizing on Knowledge: From e-business to k-business, ButtterworthHeinemann, Brilton, UK

Delors, J., Learning : The Treasure Within, Report to UNESCO of the International Commission on Education for the 21st Century, tanpa tahun;

Directorate General of Higher Education, Higher Education Long Term Strategy (HELTS) 2003 -2010; Fareed Zakaria (2004), The Future of Freedom, WW Norton Company, New York, USA

Fasli Jalal, Reformasi Pendidikan, Dalam Konteks Otonomi Daerah, Penerbit Depdiknas-BappenasAdicita Karya Nusa

Goedegebuure, et.al., Higher Education Policy: An International and Comparative Perspective, Oxford Pergamon Press, 1993;

Goodlad, S., The Quest for Quality, SRHE and Open University Press, Buckingham, 1995. Husen; Kogan (1983), Educational Research \& Policy, Pergamon Press, New York

Jerry Aldridge (2002), Current Issues and Trends in Education, Allyn and Bacon, Boston, USA

Kotter, P. (1955). The New Rules How to Succeed in Today's Post-Corporate World. New York: The Free Press, p. 42.

Lois Weiss, et all (2006) Ideology, Curriculum, and the New Sociology of Education, Informa Publishing.

Philip H. Coombs (1985), The World Crisis in Education, The View From The Eighties, Oxford University Press R. Ralph G. Lewis (1994), Total Quality in Higher Education, St Lucie Press, Delray Beach, Florida.

Robertson (1992). Globalization: Social Theory and Global Culture. London: Sage Publications, hal. 8. Sallis, E. and Jones, G. Knowledge Management in Education, Kogan Page Limited, London, 2002; Sallis, E., Total Quality Management in Education, Kogan Page Limited, London, 1993;

Samuel P. Huntington (1996), The Clash of Civilization and The Remarking of Wordl Order, Simon \& Schuster Press.

Scholte, J. A. (2000). Globalization: A critical Introduction. London: Palgrave, hal. 15-17.

Sunita S. Ahlawat, Ph.D dan Sucheta S. Ahlawat, Ph.D (2006), Competing in the Global Knowledge Economy: Implications for Business Education, Journal of American Academy of Business, Cambridge.

Thomas L. Friedman (2005), The World Is Flat, Penerbit Farrar, Straus and Giroux

Vincent Gaspersz (2001), ISO 9001:2008 and Continual Quality Improvement, Gramedia Pustaka Utama Worldwide Quality Assurance (2007), ISO 9001-2008 Quality Management System Requirements, WQA South East Asia Office. 